\title{
Home auditory training for children with impairment hearing due to cleft lip and palate
}

\author{
Lucimara de Almeida Coelho(1) \\ Marielli Fernanda Bezerra de Morais ${ }^{(1)}$ \\ Priscila de Araújo Lucas Rodrigues ${ }^{(1,2)}$ \\ Gabriela Coelho Pereira DeLuccia ${ }^{(1)}$ \\ Taina Maiza Bilinski Nardez(1) \\ Adriana Bergamasco Vieira Futigami(2) \\ Martha Takishima ${ }^{(2)}$
}

Centro Universitário de Várzea Grande UNIVAG, Várzea Grande, Mato Grosso, Brasil.

(2) Hospital Universitário Julio Muller Universidade Federal de Mato Grosso - HUJM-UFMT, Cuiabá, Mato Grosso, Brasil.

Conflict of interests: Nonexistent

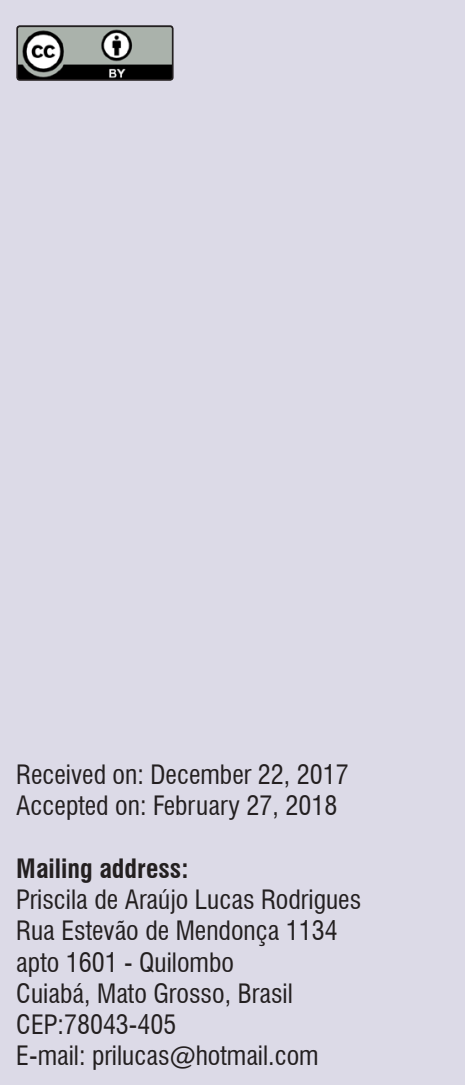

\section{ABSTRACT}

Purpose: to verify the impact of home auditory training performed by parents for 30 days and the contribution to a better performance of the central auditory processing in children with auditory disorders resulting from cleft lip and palate.

Methods: case studies were carried out with three children above seven years of age, presented with operated cleft lip and palate. Tests to assess peripheral hearing, behavioral and electrophysiological tests for central hearing assessment and Sustained Attention Auditory Ability ones, before and after the auditory training, were performed. Those responsible for the children answered a questionnaire which verified the auditory and attention behaviors altered by the impairment of the auditory processing.

Results: improvement was seen in the majority of the behavioral tests of the auditory processing disorders, and in those which did not show variation after the training, the performance was maintained. Improvement was observed in the sustained attention as well as in the monitoring of all children of the study, post training. Improvement of the auditory behavior and also the decrease of latencies and the increase of amplitude of $\mathrm{Na}$ and $\mathrm{Pa}$ waves, after the training, were found.

Conclusion: there was an enhancement in the performance of the central auditory processing of all children with operated cleft lip and palate, following auditory stimulation.

Keywords: Cleft Palate; Hearing Disorders; Rehabilitation 


\section{INTRODUCTION}

The auditory system is one of the main senses for learning and language acquisition, and for this reason the anatomical-physiological integrity of this system is considered a prerequisite not only for the language development, but also for the acquisition of the abilities to detect, pay attention to the sound, discriminate, locate where sounds come from, memorize sequences, recognize and understand sounds and speech'1.

Hearing is composed of the peripheral auditory system and central auditory system. The peripheral auditory system is composed of outer, middle and inner ear structures that have the function of capturing, transmitting and causing the sound wave transduction occurs in the cochlea ${ }^{2}$

The central auditory system is responsible for processing information such as functions of sound detection and discrimination, separation of background noise, sound understanding and recognition, and other abilities. This process occurs through the transmission of auditory information through the fibers of the VIII cranial nerve to the cochlear nuclei, brainstem, thalamus and auditory cortex².

Central Auditory Processing (CAP) can be defined as the set of mechanisms and processes responsible for the phenomena of sound lateralization and localization, for auditory discrimination, for auditory pattern recognition, for temporal aspects in audition (resolution and temporal ordering), for integration and binaural separation abilities and auditory abilities with competitive and degraded acoustic signals ${ }^{3}$. Such complex functions are assessed through the behavioral battery of the Auditory Processing (AP) performed in an acoustic booth in which distorted auditory stimuli are used so that the central nervous system capacity to analyze and interpret the presented stimulus is analyzed. It is also possible to assess central auditory functions through electrophysiological assessment ${ }^{4-6}$.

Auditory Processing Disorder (APD) is a complex and heterogeneous group of alterations usually associated with a series of auditory and learning difficulties, but there is normality of the peripheral hearing4. Among the populations of risk found with auditory processing disorders, it can be highlighted the clefts lip and palate (CLP), who suffer damage to the development of auditory abilities ${ }^{7}$.

According to an international classification, the clefts can be: pre-incisive foramen, affects the lip and alveolar arch - uni or bilateral (complete or incomplete); post-incisive foramen, affects hard palate and soft palate - uni or bilateral (complete or incomplete); trans-incisive foramen clefts, affects both regions, pre and post foramen - unilateral ( $\mathrm{R}$ or $\mathrm{L}$ ) and bilateral (complete) $^{7-9}$. In individuals with CLP, the most frequent sequelae occur in speech, voice, language and hearing and there may be frequent episodes of otitis media due to anatomical and/or functional malformations of the eustachian tubeand velopharyngeal sphincter (VPS) region $^{7-9}$.

The eustachian tubehas communication with the tympanic cavity and the nasopharynx, remaining closed for most of the time, having the functions of balancing the air pressure in the middle ear with atmospheric pressure, protecting against the pressure and secretions coming from the nasopharynx to make the drainage of these secretions, through Tensor VeliPalatini muscle, responsible for opening and closing the eustachian tubeduring swallowing. However, for this function to occur, or this process adequately it is essencialthe integrity of the palate and its structures ${ }^{7,10}$.

In individuals with CLP, mechanisms responsible for the opening of the eustachian tube are defective due to an alteration in the trajectory and insertion of the tensor and levatorvelipalatini muscles on the palate, since there is no bilateral union of these muscles in the midline and soft palate, and on the other hand, the insertion occurs at the edge of the ipsilateral cleft hard palate. This persistent tube dysfunction causes many recurrent events of otitis media, because the obstructedeustachian tubegenerates the lack of ventilation in the middle ear, increasing the production of liquid in it 7,10 .

The secretions or perforation of the tympanic membrane cause difficulties in the sound transmission, fluctuating hearing, lack of auditory stimulation, difficulty in binaural integration, distortion of the message, causing damages to the auditory, speech and spoken language development, in reading and writing, social difficulties and behavior changes ${ }^{7,11}$.

The early identification of central auditory processing disorders (CAPD) allows the speech-language pathologist an appropriate therapeutic conduct and guidances to parents and to the multidisciplinary team involved ${ }^{7}$. The speech-language pathology intervention of these patients should be specific to train the impaired auditory abilities of that individual. It can be performed in a formal manner when the training is performed in an acoustic booth called acoustically controlled auditory training (ACAT), and/or informal when it is performed in a non acoustically controlled environment and through home reinforcement with directed activities. However, 
in the Brazilian public health scenario, there is difficult related to the appropriatedequipments and trained professionals to work with central auditory processing.

A study shows that about $70 \%$ of individuals with CLP have $\mathrm{CAPD}^{7}$ and that the auditory abilities that are mainly affected are figure ground, closure and integration and binaural integration ${ }^{11-14}$.

Considering the high prevalence of CAPD in individuals with CLP or CP, the importance of early detection of CAPD alteration and home reinforcement made by the daily training of impaired auditory abilities it was hypothesized the present study. The question that guided the study was: Only the home auditory training brings some benefit to the patient? It is believed that home intervention through training with simple and easily accessible materials may be an alternative to minimize the deleterious effects of CAPD, especially in populations in which the incidence of central alteration is high as in children with CLP. It worth emphasizing that the training used in this study encompassess the main impaired auditory abilities in children with CLP and $\mathrm{CP}$ as reported in the specialized literature ${ }^{7,11-14}$ and that the exercises proposed are also endorsed in the specialized literature ${ }^{15}$.

There are means to confirm the results obtained with the auditory training, as the auditory middle latency responses (AMLR), which is an objective test, being the most indicated in the identification of Central Auditory Nervous System (CANS) alteration, which generates a series of positive and negative waves between 10 and $80 \mathrm{~ms}$ after the beginning of the acoustic stimulation, presenting a negative wave in approximately $20 \mathrm{~ms}$ and a positive peak around $30 \mathrm{~ms}^{16,17}$. The generation of the AMLR waves depends on the interaction of some brain structures like the thalamus and primary auditory cortex, which involves recognition, discrimination, figure-groundabiliaties; and non-primary, which involves selective attention, auditory sequencing and audiovisual integration ${ }^{17,18}$. The $\mathrm{Na}$ wave is the first to be recorded and the analysis of its deflection is the most important because its trace is more constant. The responses are analyzed in latency (milliseconds-ms) and in amplitude (microvolt-mv), and the decrease in intensity causes an increase in latency and a decrease in amplitude ${ }^{16-18}$. In persons who present normality to central auditory, the amplitude values of the $\mathrm{Na} \mathrm{Pa}$ waves are symmetrical between the ears, and in those individuals who present with some functional abnormality, these values are asymmetric ${ }^{16}$. According to the literature, the $\mathrm{Na}$ wave is present and reliable at birth, which the same does not occur with the Pa wave, which presents its complete maturational process around 8 to 10 years of age ${ }^{16,17}$.

The purpose of the present study was to verify the impact of the auditory training performed at home by the parents during 30 days and the contribution to a better performance of the central auditory processing in children with hearing impairment due to the cleft lip and palate.

\section{METHODS}

The study design is cross-sectional observational. Initially the project was appreciated by the Research Ethics Committee of the Júlio Muller University Hospital linked to Plataforma Brasil and approved by the number 56644316.6.0000.5541. Those responsible for the participants signed the Informed Consent Form (ICF).

The inclusion criterion was to present CLP or CP surgically corrected, older than seven years, without peripheral hearing loss. About 30 patients from an outpatient attendance to cleft patient were found in the proposed inclusion criteria, however, due to the outdated phones, the number of patients in the study was reduced. In this way, three children who met the inclusion criteria were recruited. Patients who did not attend any stage proposed in the study or who presented multiple disabilities were excluded.

Initially, the selected patients attended the clinic of the University Center in Várzea Grande- UNIVAG, for two hours, to be assessed through the following exams:

- Meatoscopy

- Tympanometry

- PureTone Audiometry

- Behavioral Assessment of Central Auditory Processing

- Sustained Auditory Attention Ability Test (SAAAT) Immediately after the abovementioned assessments, the patients attended the JMUH for 30 minutes to perform the following procedure:

- Auditory Middle Latency Responses (AMLR) The procedures performed and the reference standards used are described below.

1. Meatoscopy: To check the presence of any foreign body that prevents the assessment.

2. Tympanometry: Contributes to identify alterations of the middle ear, investigating the integrity of the tympano-ossicular system. The reference criterion used to analyze tympanometry was the Jerger (1970) classification in which the mobility of the tympano-ossicular system is considered as: A curve 
- normality (compliance of $0.3-1.6 \mathrm{ml}$ ), Ad curve hypermobility (compliance above $1.6 \mathrm{ml}$ ), Ar curve - low mobility (compliance below $0.3 \mathrm{ml}$ ), B curve - no mobility (no peak) and C curve when there is air pressure in the middle ear and it is found diverted to negative pressures ${ }^{19}$.

3. Pure Tone Audiometry: An instrument used to diagnose auditory disorders in which the following frequencies were evaluated: $1 \mathrm{KHz}, 2 \mathrm{KHz}, 3 \mathrm{KHz}$, $4 \mathrm{KHz}, 6 \mathrm{KHz}, 8 \mathrm{KHz}, 500 \mathrm{KHz}$ and $250 \mathrm{KHz}$, being used the normality criterion proposed by the World Health Organization - WHO 2014²0.

4. Central auditory processing tests: Behavioral procedures that functionally analyze the central auditory system $^{6}$, carried out in an acoustic booth, distorted auditory stimuli being used to verify the capacity of the central nervous system to analyze and interpret the stimuli that were presented ${ }^{6}$. For the CAD assessment, the following standardized tests for the Brazilian population were performed 6 :

- Localization Test: Assesses the auditory ability to locate the sound source. The patient is seated with eyes closed. The therapist with the rattle instrument presents the sound to the patient in the five directions: right, left, front, back and above the head and the patient locates and point where the sound comes from.

- Non-verbal Sequential Memory Test: Assesses the auditory memory ability for non-verbal sounds. The patient seats with sealed eyes, and hears three different sounds (coconuts, rattle and bell) in three random sequences, and tells what the sounds and sequence heard were.

- Verbal Sequential Memory Test: Diotic test in which the syllables PA TA CA and FA are presented without visualcues, and the patients are instructed to repeat the sequence that has been presented. The test assesses the auditory memory ability for verbal sounds.

- Speech in Noise Test (SNT): Monotic test, assesses the closure ability, in which ten monosyllable words with white noise are presented in the same ear (hand, ox, train, goal, sun, foot, bread, flower, sky - mão, boi, trem, gol, sol, pé, pão, flor, céu). The patients listen the words and point out on the board the figures that correspond to the sound heard. It is performed with an intensity of $40 \mathrm{dBSL}$ signal-to-noise ratio of $-10 \mathrm{~dB}$.

- PSI-MCI Test (Pediatric Speech Inteligibility): Monotic test that assesses the figure ground ability, in which 10 sentences corresponding to the main message at the intensity of $40 \mathrm{dBSL}$ are presented to the patients, simultaneously to a competitive message, in which the patient listens to the sentence and point on the board, the figure corresponding to the sentence heard. It is performed in the signal-to-noise ratio of 0 and $-10 \mathrm{~dB}$.

- Non-verbal dichotic test of directed listening: Dichotic test that assesses the figure ground ability to non-verbal sounds. Twelve pairs of sounds (thunder, church bell, opening door, cat meowing, dog barking and rooster cackling) (trovão, sino da igreja, porta abrindo, gato miando, cachorro latindo e galo cacarejanto) are presented dichotically at 50 dBSL. It is performed in 2 stages: in the first stage, free attention in which the patient points the figure corresponding to the sound he/she heard more clearly. In the second stage, listening directed to the right ear and left ear, the patient points to the board the figures he/she heard in the right ear and then in the left ear.

- Dichotic Digits Test: Dichotic Test which assesses the figure ground ability for verbal sounds: 80 disyllabic numbers consisting of 4 digits are presented: two in each ear simultaneously in which the patient repeats the four digits presented, thus, assessing the binaural integration. It is performed at the intensity of $50 \mathrm{dBSL}$.

- Frequency Pattern Test (FPT): DióticTest performed at the intensity of $50 \mathrm{dBSL}$, assesses the temporal ordering ability. It consists of the presentation of 10 sequences with three stimuli that vary their frequency (low and high). In this way, the patient's response should be exactly the sequence of sounds he/she heard.

5. Sustained Auditory Attention Ability Test (SAAAT): Behavioral test of simple and rapid application, it has the aim of assessing the sustained auditory attention ability of children from 6 to 11 years of age, in which the individual should maintain monitoring and respond to the presence or absence of a target stimulus. The test consists of 21 monosyllabic words recorded in a male voice, one word per second is displayed, in which they are repeated randomly, forming a list of 100 words and 20 occurrences of the target word " no, "also arranged in a random manner. The words are presented six times without interruption, analyzing the total score of the errors and the decrease of monitoring (quantitative difference of errors between the first and sixth sequence 
of presentation of the monosyllables). Two types of errors are considered: inattention - when the child loses attention and does not raise his/her hand in response to the target word ("no") and impulsivity - when the child raises his/her hand to other word instead of the word "no". The normality standard for children who are six, seven and eight years of age is 49.36 and 33 errors in the total score, respectively. The decrease in monitoring for the three ages is seven errors ${ }^{21}$.

6. Auditory Middle Latency Responses (AMLR): Objective test, in which bioelectrical responses captured by electrodes fixed in the right and left mastoid and in the forehead that occur between 10 and $80 \mathrm{~ms}$ after the auditory stimulus, characterized by negative peak $(N)$ and positive peak $(P)$ waves represented: $\mathrm{Na}, \mathrm{Pa}$, being $\mathrm{Pa}$, more consistent and frequent, more suitable for diagnosis. The electrodes were fixed with microporous adhesive after cleaning the skin with abrasive paste and electrolytic paste was used to improve the electrical conductivity. The impedance of each electrode did not exceed 5 Kohms and did not exceed 2 Kohms between the impedances of the electrodes. It was used monoaural click stimulus rarefied at $80 \mathrm{dBHL}$ of $100 \mathrm{~ms}$ duration with presentation rate of 5 stimuli/second, analysis time of $100 \mathrm{~ms}$, acoustic filter of 10 to $100 \mathrm{~Hz}$ and amplification of 50,000 $x$. The patients were mounted with electrodes in $\mathrm{Cz}$ (active electrode), Fpz (ground), A1 (reference electrode-left ear) and A2 (reference electrode-right ear). The latency (ms) of the $\mathrm{Na}, \mathrm{Pa}$ waves and the $\mathrm{Na}-\mathrm{Pa}(\mu \mathrm{V})$ amplitude were analyzed.

The equipment used for the aforementioned assessments were:

- Otoscope: Brand: Hiene, Model: mini 3000

- Audiometer: Brand: Audiometer, Model: Resonance

- Immitanciometer: Brand: Interacoustics, Model: AT-235

- CD player: Brand: Philips, Model: USB DIRECT CD SOUNDMACHINE AZ3811

- Medium latency potential analyzer: Brand: Nihonkohden, Model: MEB 9400

On the day of the assessment, the responsible answered a questionnaire called Scale of Auditory Behaviors ( $\mathrm{SAB}$ ) in order to verify which behaviors of the individual could be altered by the auditory processing disorder. The questionnaire (SAB) presents a version that can be filled out by parents or teachers. It is normalized based on a study with 96 children between 4 and 6 years of age ${ }^{15}$. The instrument has 12 questions most frequently related to AP. The questionnaire is easy to apply because it contains a small number of questions and closed options that are easy to understand.

Soon after, the responsible were instructed in terms of the auditory training that should be carried out at home, being delivered a guideline booklet with the proposed exercises and the following materials to carry out the training: rattle and whistle. The proposed auditory training aims to work some central auditory abilities in a simple way and with materials of easy access to the population, with tasks already described in the literature ${ }^{15}$. The abilities worked and procedures that were used will be demonstrated bellow:

- Localization: Close the child's eyes, tap a fork in the glass or plastic cup in several directions and ask the child to point to where the sound came from. Perform in five directions: Right, left, front, back and above the head.

- Attention: Close the child's eyes, turn on a song on the radio or cell phone. Cough and ask the child to count how many times you coughed. Sit behind the child. Repeat the task by taking two steps back.

- Auditory closure:Close the child's eyes, turn on a song on the radio or cell phone. Ask the child to repeat 10 words you speak. To sit behind the child. Repeat the task by taking two steps back. The words were pre-defined by researchers and equal to all participants.

- Temporal ordering: Close the child's eyes, get a glass and the whistle. Make a sequence with three sounds, varying between glass and whistle and ask the child to say the order they were output. The sequence of sounds was pre-defined by researchers and equal to all participants.

The auditory training was carried out during 30 days (Monday to Friday with rest on weekends) with a total duration of approximately 15 minutes, being performed at a time the parents' choice since the child was willing to do it. The training was monitored by one of the researchers who called daily to the responsble in order to check if the exercises were being done. After the 30 days of training, the patients were assessedagain by the procedures proposed above in order to verify if there was an improvement of the auditory abilities worked after the training. Again, the SAB questionnaire was applied to verify the impact of auditory training on the patient's daily life. 
At the end of the data collection, a comparative descriptive analysis of the patients' performance was performed in the assessment of the behavioral test of auditory processing, SAB and SAAAT pre and post home training.

\section{RESULTS}

Table 1 shows the results of pure tone audiometry performed in the three children and the results of tympanometry of the same ones performed pre and post home auditory training. All children assessed had no otitis at the time of assessment and normal hearing thresholds in both ears. They were individuals with operated CLP.

Table 1. Results of pure tone audiometry and tympanometry carried out pre and post home auditory training

\begin{tabular}{|c|c|c|c|c|}
\hline & \multicolumn{2}{|c|}{ Pure Tone Audiometry } & \multicolumn{2}{|c|}{ Tympanometry } \\
\hline & Pre-Training & Post-Training & Pre-Training & Post-Training \\
\hline E.G (7 years) & $\begin{array}{l}\text { Normal hearing } \\
\text { thresholds }\end{array}$ & $\begin{array}{l}\text { Normal hearing } \\
\text { thresholds }\end{array}$ & tympanogram type A & tympanogram type A \\
\hline L.O (8 years) & $\begin{array}{l}\text { Normal hearing } \\
\text { thresholds }\end{array}$ & $\begin{array}{l}\text { Normal hearing } \\
\text { thresholds }\end{array}$ & tympanogram type A & tympanogram type A \\
\hline G.V (7 years) & $\begin{array}{c}\text { Normal hearing } \\
\text { thresholds }\end{array}$ & $\begin{array}{l}\text { Normal hearing } \\
\text { thresholds }\end{array}$ & tympanogram type $\mathrm{C}$ & tympanogram type $\mathrm{C}$ \\
\hline
\end{tabular}

Table 2 shows the results of SAAAT- Sustained Auditory Attention Ability Test. It was observed that there was improvement in the sustained attention (total score) and in the monitoring of all children in the study after the period of home training.

Table 2. Results of the sustained auditory attention ability test

\begin{tabular}{cccc}
\hline & Pre-training & Post-training & Expected score for age \\
\hline Inattention & & & \\
E.G. (7 YEARS) & 27 & 8 & \\
L.O. (8 YEARS) & 42 & 24 & \\
G.V. (7 YEARS) & 15 & 0 & \\
\hline Impulsiveness & & 7 & \\
E.G. (7 YEARS) & 25 & 10 & 35 \\
L.O. (8 YEARS) & 16 & 1 & 32 \\
G.V. (7 YEARS) & 13 & & 35 \\
\hline Total SCOre & 52 & 15 & 7 \\
E.G. (7 YEARS) & 58 & 1 & 7 \\
L.O. (8 YEARS) & 28 & & 7 \\
G.V. (7 YEARS) & & 1 & \\
\hline Decrease of monitoring & 4 & 2 & \\
E.G. (7 YEARS) & 7 & 0 & \\
L.O. (8 YEARS) & 1 & & \\
G.V. (7 YEARS) & &
\end{tabular}


Table 3 presents the results of behavioral assessments of Central Auditory Processing. There was improvement in CAP abilities tested after home training in most of the applied tests. In the tests that did not show variation after the training, maintenance of performance was seen.

Table 3. Results of behavioral assessments of central auditory processing

\begin{tabular}{|c|c|c|c|c|c|}
\hline & \multicolumn{2}{|c|}{ Pre-training } & \multicolumn{2}{|c|}{ Post-training } & $\begin{array}{c}\text { Expected score for } \\
\text { age }\end{array}$ \\
\hline \multicolumn{6}{|l|}{ LOC } \\
\hline E.G. (7 YEARS) & \multicolumn{2}{|c|}{$4 / 5$} & \multicolumn{2}{|c|}{$4 / 5$} & $4 / 5$ successes \\
\hline L.0. (8 YEARS) & \multicolumn{2}{|c|}{$4 / 5$} & \multicolumn{2}{|c|}{$4 / 5$} & $4 / 5$ successes \\
\hline G.V. (7 YEARS) & \multicolumn{2}{|c|}{$4 / 5$} & \multicolumn{2}{|c|}{$4 / 5$} & $4 / 5$ successes \\
\hline NVSM & & & & & \\
\hline E.G. (7 YEARS) & \multicolumn{2}{|c|}{$1 / 3$} & \multicolumn{2}{|c|}{$0 / 3$} & 2/3 successes \\
\hline L.0. (8 YEARS) & \multicolumn{2}{|c|}{$1 / 3$} & \multicolumn{2}{|c|}{$3 / 3$} & 2/3 successes \\
\hline G.V. (7 YEARS) & \multicolumn{2}{|c|}{$2 / 3$} & \multicolumn{2}{|c|}{$2 / 3$} & 2/3 successes \\
\hline VSM & \multirow{2}{*}{\multicolumn{2}{|c|}{$0 / 3$}} & \multirow{2}{*}{\multicolumn{2}{|c|}{$1 / 3$}} & \\
\hline E.G. (7 YEARS) & & & & & 2/3 successes \\
\hline L.0. (8 YEARS) & \multicolumn{2}{|c|}{$1 / 3$} & \multicolumn{2}{|c|}{$2 / 3$} & 2/3 successes \\
\hline G.V. (7 YEARS) & \multicolumn{2}{|c|}{$2 / 3$} & \multicolumn{2}{|c|}{$2 / 3$} & $2 / 3$ successes \\
\hline $\mathrm{PSI}(\mathrm{SNR}=0 \mathrm{~dB})$ & OD & $\mathrm{OE}$ & OD & $\mathrm{OE}$ & \multirow{8}{*}{$\begin{array}{l}\text { SNR (0): } 80 \% \\
\text { SNR (-15): } 60 \%\end{array}$} \\
\hline E.G. (7 YEARS) & $20 \%$ & $60 \%$ & $100 \%$ & $60 \%$ & \\
\hline L.0. (8 YEARS) & $100 \%$ & $100 \%$ & $100 \%$ & $100 \%$ & \\
\hline G.V. (7 YEARS) & $60 \%$ & $80 \%$ & $80 \%$ & $90 \%$ & \\
\hline PSI $(S N R=-15 \mathrm{~dB})$ & OD & $\mathrm{OE}$ & $\mathrm{OD}$ & $\mathrm{OE}$ & \\
\hline E.G. (7 YEARS) & $20 \%$ & $0 \%$ & $60 \%$ & $0 \%$ & \\
\hline L.0. (8 YEARS) & $60 \%$ & $40 \%$ & $60 \%$ & $60 \%$ & \\
\hline G.V. (7 YEARS) & $40 \%$ & $60 \%$ & $100 \%$ & $70 \%$ & \\
\hline FN & OD & $\mathrm{OE}$ & OD & $\mathrm{OE}$ & \\
\hline E.G. (7 YEARS) & $100 \%$ & $100 \%$ & $100 \%$ & $100 \%$ & $\mathrm{RE}: \geq 90 \%$ \\
\hline L.O. (8 YEARS) & $50 \%$ & $40 \%$ & $60 \%$ & $50 \%$ & LE: $\geq 90 \%$ \\
\hline G.V. (7 YEARS) & $50 \%$ & $40 \%$ & $70 \%$ & $70 \%$ & \\
\hline \multicolumn{6}{|l|}{ NVD } \\
\hline Free Attention & OD & $\mathrm{OE}$ & OD & $\mathrm{OE}$ & \multirow{4}{*}{$\begin{array}{c}\text { FA: } 5 \text { a } 7 \\
\text { successesfor each } \\
\text { ear }\end{array}$} \\
\hline E.G. (7 YEARS) & 5 & 7 & 5 & 7 & \\
\hline L.0. (8 YEARS) & 3 & 7 & 4 & 7 & \\
\hline G.V. (7 YEARS) & 9 & 3 & 6 & 6 & \\
\hline Directed Listening & OD & $\mathrm{OE}$ & OD & $\mathrm{OE}$ & DLR: $\geq 11$ \\
\hline E.G. (7 YEARS) & 6 & 7 & 6 & 7 & successes \\
\hline L.O. (8 YEARS) & 4 & 5 & 9 & 7 & DLL: $\geq 11$ \\
\hline G.V. (7 YEARS) & 12 & 11 & 12 & 12 & successes \\
\hline DDT & OD & $\mathrm{OE}$ & OD & $\mathrm{OE}$ & \\
\hline E.G. (7 YEARS) & $20 \%$ & $62.5 \%$ & $35 \%$ & $67.5 \%$ & $\mathrm{RE}: \geq 85 \%$ \\
\hline L.0. (8 YEARS) & $87.5 \%$ & $10 \%$ & $87.5 \%$ & $60 \%$ & LE: $\geq 82 \%$ \\
\hline G.V. (7 YEARS) & $92.5 \%$ & $100 \%$ & $100 \%$ & $92.5 \%$ & \\
\hline \multicolumn{6}{|l|}{ FPT } \\
\hline E.G. (7 YEARS) & & & & & \\
\hline L.0. (8 YEARS) & & & & & Above 70\% \\
\hline G.V. (7 YEARS) & & & & & \\
\hline
\end{tabular}

Legend: LOC: Localization; NVSM: Non-verbal sequential memory; VSM: Verbal sequential memory; PSI: Pediatric Speech Intelligibility; FN: Identification Figure Test in noisy; NVD: Non-verbal Dhicotic; DDT: Dichotic digits test; FA: Free Attention; AR: Attention to the right; AL: Attention to the left; RE: right ear; LE: left ear; SNR: signalto-noise ratio: DLR: Direct listening to the right; DLL: Direct listening to the left; NRR: No reliable response; FPT: Frequency Pattern Test 
The results presented in Table 4 indicate the responses of the Self Assessment Protocol (SAB) in children with cleft lip and palate. There was an improvement in the post-training auditory behavior of these children, through the parents' responses by means of SAB.
Finally, Table 5 shows the data from the collection of the Auditory Middle Latency Responses (AMLR). The latencies of $\mathrm{Na}$ and $\mathrm{Pa}$ waves decreased after the AT at home and there was an increase in the amplitude of the $\mathrm{Na}-\mathrm{Pa}$ waves in a patient of the study.

Table 4. Results of the responses of the Self-Assessment Protocol (SAB)

\begin{tabular}{|c|c|c|c|c|c|c|}
\hline \multirow[b]{2}{*}{ Behavior Items (Assessment) } & \multicolumn{2}{|c|}{ E.G. (7 years) } & \multicolumn{2}{|c|}{ L.0. (8 years) } & \multicolumn{2}{|c|}{ G.V. (7 years) } \\
\hline & Pre-Training & Post-Training & Pre- Training & Post-Training & Pre- Training & $\begin{array}{l}\text { Post- } \\
\text { Training }\end{array}$ \\
\hline $\begin{array}{l}\text { Difficulty in listening or understanding in } \\
\text { a noisy environment? }\end{array}$ & 3 & 5 & 3 & 5 & 5 & 3 \\
\hline $\begin{array}{l}\text { Do not understand well when someone } \\
\text { talks fast or "stuffy"? }\end{array}$ & 1 & 3 & 5 & 5 & 3 & 5 \\
\hline Difficulty in following oral instructions? & 3 & 5 & 3 & 3 & 3 & 4 \\
\hline $\begin{array}{l}\text { Difficulty in identifying and } \\
\text { discriminating speech sounds? }\end{array}$ & 1 & 5 & 5 & 5 & 2 & 5 \\
\hline $\begin{array}{l}\text { Inconsistency of response to auditory } \\
\text { information? }\end{array}$ & 2 & 5 & 2 & 3 & 5 & 5 \\
\hline Poor reading skill? & NA & NA & 4 & 5 & 5 & 5 \\
\hline Ask to repeat things? & 1 & 3 & 1 & 5 & 4 & 3 \\
\hline Easily distracted? & 1 & 5 & 1 & 3 & 1 & 2 \\
\hline Academic or learning difficulties? & 5 & 5 & 5 & 5 & 5 & 5 \\
\hline Short attention period? & 1 & 5 & 2 & 2 & 3 & 5 \\
\hline Dream awake, seem inattentive? & 5 & 5 & 3 & 3 & 2 & 2 \\
\hline Disorganized? & 2 & 5 & 1 & 1 & 5 & 1 \\
\hline TOTAL SCORE & 25 & 51 & 35 & 45 & 43 & 45 \\
\hline
\end{tabular}

Legend:1.Frequent; 2.Almost always; 3.Sometimes; 4. Sporadically; 5.Never; NA:Not applied

Table 5. Results of auditory middle latency responses

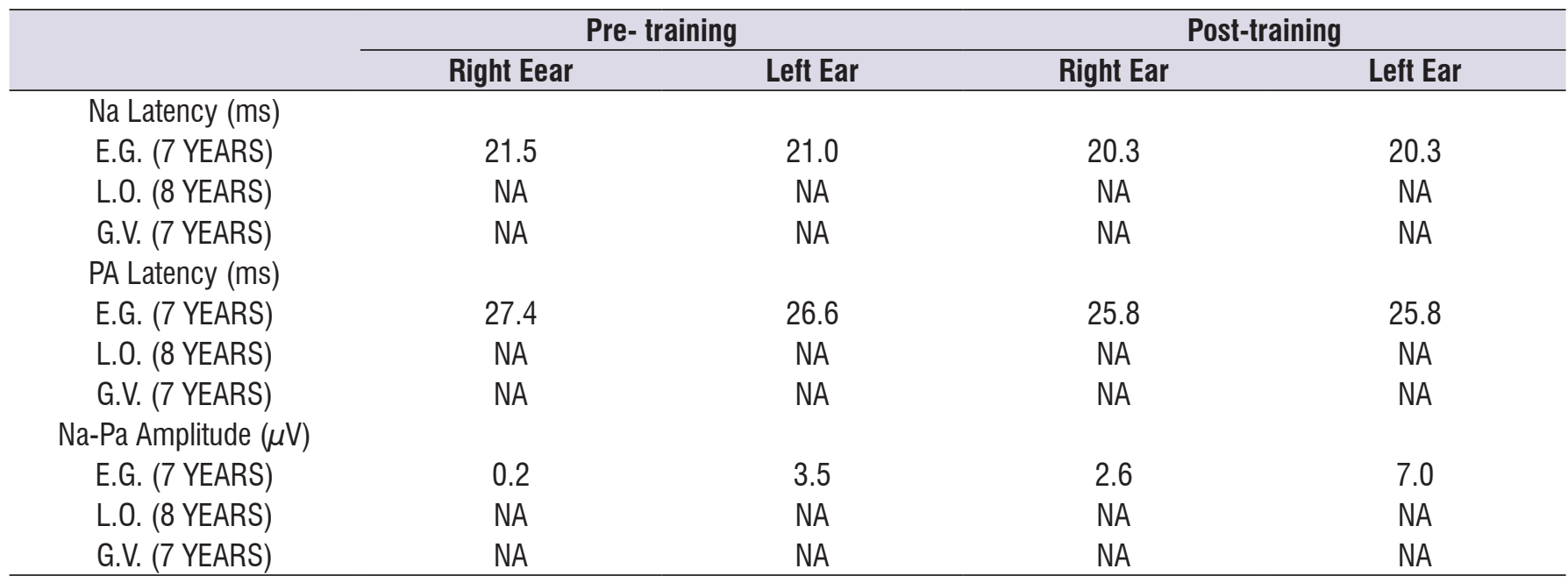

Legend: NA: No answer 


\section{DISCUSSION}

The relationship between CAP disorders in children with CLP is widely discussed in the literature and has as a causal factor the constant alteration of ME found in these patients. This chronic alteration of ME occurs due to malformation of the eustachian tube, caused by an alteration in the trajectory and insertion of the muscles: tensor and levatorvelipalatini on the ipsilateral hard palate, being that the normality is their insertion bilaterally ${ }^{7,10}$. This alteration brings as consequence the malfunctioning of the eustachian tube that remaining closed most of the time, without ventilation, produces a fluid in the ME and recurrent episodes of otitis media. These secretions, housed in ME, impair the sound transmission, with fluctuation and inconsistency in the hearing, resulting in difficulty in binaural integration, distortion of the message and impairments in language development and auditory processing, in terms of: organization, categorization of acoustic information, reception, expression and comprehension of sound and message ${ }^{7}$. In this study, children with CLP present normal hearing and tympanogram type $C$, due to chronic alterations in ME, as demonstrated in Table 1.

The expectation generated by the home auditory training applied in this study was that individuals would improve some of their central auditory abilities that were altered. Therefore, it is worth mentioning that learning consists of an acquisition, conservation and evocation of knowledge process and occurs from modifications in the Central Nervous System (CNS) relatively permanent when the individual is subjected to stimuli and or experiences that are translated by brain modifications ${ }^{22}$. The understanding about the nature of structural changes of the encephalon in the learning process passes through the knowledge of the biochemical and functional characteristics of the neurons, the synapses and the circuits formed by them and attention and memory are essential for any learning to occur ${ }^{22}$.

The literature reports that intermittent sensory deprivation in children with FLP, as a result of changes in $\mathrm{ME}$, cause alterations in auditory abilities, especially in attention ability to sound ${ }^{23-25}$, which agrees with the findings of the present study as demonstrated in Table 2. The auditory attention ability is essential for the sound and language acquisition and is essential in the learning process of reading and writing, and can be evaluated by the SAAAT test that was developed to measure the child's sustained attention, allowing the child to listen for a period of time and respond only to a specific stimulus ${ }^{23,25}$. It can be stated that the SAAAT application in the evaluation of patients with cleft in this study contributed to show the improvement in the sustained attention and monitoring of all children in the study after the period of home training.

The literature reports that intermittent sensory deprivation in children with CLP, as a result of alterations in $\mathrm{ME}$, generates alterations in auditory abilities, especially in attention to sound ability ${ }^{23-25}$, which agrees with the findings of the present study as demonstrated in Table 2. A auditory attention is essential for the sounds and language acquisition and it is essential in the learning process of reading and writing, and can be assessed by the SAAAT test that was developed to measure the child's sustained attention, allowing the child to listen for a prolonged period of time and respond only to a specific stimulus ${ }^{23,25}$. It can be stated that the application of SAAAT in the assessment of patients with clefts in this study contributed to show the improvement in the sustained attention and monitoring of all children in the study after the period of home training.

According to Table 3, the analysis of the behavioral assessment of CAP performed in this study shows that the work performed by the parents at home was able to improve the quantitative scores of some tests, even though the results have still remained altered. Other similar studies demonstrate an improvement in the performance of the patients after formal AT and after the informal $\mathrm{AT}^{26-29}$. This improvement can be justified by the neural plasticity in which the stimulation of the auditory abilities enables an "activation" of the neural plasticity, in this way, the chances of successful rehabilitation are increased ${ }^{26}$.

The literature reports that even if the acoustically controlled auditory training is not performed, the informal AT can fulfill the stimulation of auditory abilities in the same way, since it is in an organized manner ${ }^{27-29}$. However, studies show that for permanent changes in auditory behavior the AT should be performed for more than three months of stimulation, because it is during this period that myelin develops ${ }^{30}$.

The impact of the behavioral changes observed in auditory processing tests can be seen in the parents' reports as observed in Table 4. Studies which usedthe SAB suggest that children between 8 and 12 years of age should present a mean final score of 46 points and that the presence of values lower than this indicates a risk situation for the CAP ${ }^{31,32}$. In this study, it was noticed that after the ATat home, there was an improvement in the parents' perception interms of the auditory behavior of the children, even with a short stimulation time. 
According to Table 5, it was possible to analyze the electrophysiological data of only one patient, through the visualization of $\mathrm{Na}$ and $\mathrm{Pa}$ waves, with more robust responses. The literature cites that the responses of the medium latency waves demonstrate more reliable between 8 and 10 years of age, period in which the process of neuronal maturation becomes complete. Therefore, absences or delays in the records inchildren younger than 10 years should not be interpreted as abnormalities, once they may be due to maturational factors. However, above this age, such findings suggest involvement of the central auditory system ${ }^{16,17}$.

In the present study the latencies of the $\mathrm{Na}$ and $\mathrm{Pa}$ waves decreased after the AT at home and there was an increase in the amplitude of the $\mathrm{Na}$-Pa wavecomplex. The improvement in the latency of these waves shows that there was an increase in the transmission velocity of the auditory potential in the thalamus and consequently the structures of the auditory pathway that precede the thalamus (vestibulocochlear nerve and brainstem) suggesting a better performance of auditory abilities in front of the AT at home, especially the selective attention ability ${ }^{17}$. The increase in the amplitude of the $\mathrm{Na}-\mathrm{Pa}$ wave reveals that there was a greater amount of neuronal fibers activated post-training. It is emphasized that the analysis of the latency and amplitude of the AMLR is reliable and adequate to monitor the auditory rehabilitation, because there is a reliability in the records of these potentials. The literature reports that once the AMLR is performed again within the period of one year the responses will always demonstrate stable ${ }^{33,34}$.

The present study demonstrated that the informal home auditory training performed by the parents of children with cleft using easy access materials enhances at least the attentional capacity of the patients, which is the basis for any learning. It is worth highlighting that only home training is not effective in resolving the central disorders. The results presented corroborate the importance of the use of acoustically controlled training linked to the support of informal training and home exercises for a good prognosis. It should be emphasized that the limitations found in the present study, such as the restricted amount of the sample and difficulty in controlling the variable frequency of home training, because the parents can change the information given about the AT.

Although the present study has evidenced relevant contributions to sustained attention and in several aspects of CAD, the application of the proposal should be corroborated by new studies involving a larger sample to allow statistical analysis, and longer time of home training with diversified and controlled strategies.

\section{CONCLUSION}

The home auditory training improved the attention capacity and some central auditory abilities in the patients with operated cleft lip and palate. Although it was not enough to relieve the central auditory alterations presented, the improvement of central auditory processing performance of the children with auditory disorders, due to cleft lip and palate after stimulation, occurred.

\section{REFERENCES}

1. Luiz CBL, Garcia MV, Perissinoto J, Goulart AL, Azevedo MF de. Relation between auditory abilities in the first year of life and language diagnosis in pre-terms. Rev. CEFAC. 2016;18(6):1316-22.

2. Carvalho NG de, Novelli CVL, Santos MFC. Factors in childhood and adolescence that may influence the auditory processing: a systematic review.Rev CEFAC . 2015;17(5):1590-603.

3. American Speech-Language-Hearing Association - ASHA. (Central) Auditory processing disorders: technical report. 2005. [acesso em: Agosto 2017]. Disponível em: URL: http: //www.asha.org/ members/deskref-journals/deskref/default.

4. Alonso R, Schochat E. The efficacy of formal auditory training in children with (central) auditory processing disorder: behavioral and electrophysiological evaluation.Braz J Otorhinolaryngol. 2009;75(5):726-32.

5. Verdun NM, Zwetsch IC, Ferreira MIDC. Caracterização dos tipos de erros cometidos na avaliação do processamento auditivo por meio do staggered spondaic word test. Rev. CEFAC.2015;17(6):1848-54.

6. Pereira LD, Frota S. Avaliação do processamento auditivo: Testes comportamentais. In: Boéchat EM, Menezes PL, Couto CM, Frizzo ACF, Scharlach RC, Anastasio ART (org). Tratado de Audiologia. 2a ed. Rio de Janeiro: Guanabara Koogan; 2015. p. 160-70.

7. Amaral MIR, Martins JE, Santos MFC. A study on the hearing of children with non-syndromic cleft palate/ lip.Braz JOtorhinolaryngol. 2010;76(2):164-71.

8. Silva EB, Fúria CLB, Di Ninno CQMS. Aleitamento Materno em Recém nascidos portadores de fissura 
labiopalatina: dificuldades e métodos utilizados. Rev. CEFAC. 2005;7(1):21-8.

9. Baroneza JE, Salles De Faria MJS, Kuasne H, Do Val Carneiro JL, De Oliveira JC. Dados epidemiológicos de portadores de fissuras labiopalatinas de uma instituição especializada de Londrina, Estado do Paraná. Acta Sci - Heal Sci. 2005;27(1):31-5.

10. Santos FR, Penna SHAP, Brandão GR. Avaliação audiológica pré-cirurgia otológica de indivíduos com fissura labiopalatina operada. Rev. CEFAC. 2001;13(2):271-80.

11. Balbani APS, Montovani JC. Impacto das otites médias na aquisição da linguagem em crianças. Jornal de Pediatria. 2003;79(5):391-6.

12. Cardoso YMP, Cardoso MCDAF, Costa-Ferreira MID da. Correlação entre fissura labiopalatina e processamento auditivo (central). Univ Ciências da Saúde. 2014;12(2):91-8.

13. Lemos ICC, Monteiro CZ, Camargo RA, Rissato ACS, Feniman MR. Dichotic Listening Test (directed attention mode) in children with cleft lip and palate. Braz J Otorhinolaryngol. 2008;74(5):662-7.

14. Boscariol M, Feniman R. Cleft palate children: performance in auditory processing tests.BrazJ Otorhinolaryngol. 2009;75(2):213-20.

15. Nunes CL. Rastreio do processamento auditivo em crianças portuguesas. In: Nunes CL. Processamento auditivo - conhecer, avaliar e intervir. 1a ed. Lisboa: Papa-Letras; 2015.p.28-34.

16. Oliveira ACS, Regaçone SF, Frizzo ACF. Middle latency auditory evoked potential in child population. J Hum Growth Dev. 2016;26(3):368-73.

17. Matas CG, Magliaro FCL.Aplicações clínicas dos potenciais evocados auditivos de curta e média latências. In: Marchesan IQ, Silva $\mathrm{HJ}$, Tomé MC (orgs).Tratado das Especialidades em Fonoaudiologia. 1a ed.Rio de Janeiro: Roca; 2014.p.1504-14.

18. Frizzo AC, Reis ACMB. Potenciais evocados auditivos de média e longa Latências. In: Marchesan IQ,Silva HJ, Tomé MC (orgs). Tratado das Especialidades em Fonoaudiologia. 1a ed. Rio de Janeiro: Roca; 2014.p. 1515-8.

19. Jerger J. Clinical experience with audiometry. ArchOtolaryngol. [Internet]. 1970 [acesso em 25.10.17]; 92(4):311-24. Avaiable from: https:// jamanetwork.com/journals/jamaotolaryngology/ article-abstract/603185? redirect $=$ true

20. OrganizaçãoMundial da Saúde-OMS. Grades of hearing impairment. 2014. Avaiable from:

http://www.who.int/pbd/deafness/ hearing_impairment_grades/en/

21. Feniman MR, Ortelan RR, Campos CF, Cruz MS, Lauris PJ. Manual de instruções - parâmetros normais encontrados[base de dados na Internet]. Bauru (SP): Faculdade de Odontologia de Bauru da Universidade de São Paulo - FOB-USP;2007. Acesso em 21 de Setembro de 2017, disponível em Teste de Atenção Auditiva Sustentada: http://www. thaas.fob.usp.br/manual-de-instrucoes.php

22. Ohlwiler L. Fisiologia e neuroquímica da aprendizagem. In: Rotta NT, Ohlwiler L, Riesgo RS (orgs). Transtornos da aprendizagem: abordagem neurobiológica e multidisciplinar. 2aed. Porto Alegre: Artmed; 2016. p.28-42.

23. Lemos ICC, Feniman MR. Sustained Auditory Attention Ability Test (SAAAT) in sevenyear-old children with cleft lip and palate.Braz j otorhinolaryngol. 2010;76(2):199-205.

24. Feniman MR, Souza TC, Teixeira TS, Mondelli MFCG. Percepção dos pais sobre a habilidade de atenção auditiva de seu filho com fissura labiopalatina: estudo retrospectivo. Arq Int Otorrinolaringol. 2012;16(1):115-20.

25. Feniman MR, Ortelan RR, Lauris JRP, Campos CF, Cruz MS. Proposta de instrumento comportamental para avaliar a atenção auditiva sustentada. Braz J Otorhinolaryngol. 2007;73(4):523-7.

26. Cruz ACA, Andrade AN, Gil D. Effectiveness of formal auditory training in adults with auditory processing disorder. Rev. CEFAC. 2013;15(6):1427-34.

27. Melo Â, Costa MJ, Garcia MV, Filha VAVS, Biaggio EPV. The use of software on auditory training in children: theoretical review. Rev. CEFAC. 2015;17(6):2025-32.

28. Vilela N, Wertzner HF, Sanches SGG, Lobo IFN, Carvalho RMM. Temporal processing in children with phonological disorders submitted to auditory training: a pilot study. J Soc Bras Fonoaudiol. 2012;24(1):42-8.

29. Samelli AG, Mecca FFDN. Treinamento auditivo para transtorno do processamento auditivo: uma proposta de intervençãoterapêutica.Rev. CEFAC. 2010;12(2):235-41.

30. Dias KZ, Gil D. Treinamento auditivo acusticamente controlado nos distúrbios de processamento auditivo. In: Boéchat EM, Menezes PL, Couto CM, Frizzo ACF, Scharlach RC, Anastasio ART (orgs). Tratado de Audiologia. 2a ed. Rio de Janeiro: Guanabara Koogan; 2015. p. 534-40. 
31. Nunes CL, Pereira LD, Carvalho GS de. Scale of Auditory Behaviors and auditory behavior tests for auditory processing assessment in Portuguese children. CoDAS. 2013;25(3):209-15.

32. Miranda AR, Bruera JA, Serra SV. Scale of auditory behaviors: normative reference values for healthy argentinian children. ACTA neuropsychologica, 2016;15(2):119-26.

33. Almeida FS, Pialarissi PR, Júnior EFP, Almeida MAO, Silva A. Respostas auditivas evocadas de latência média: um estudo de padronização. Braz J Otorhinolaryngol. 2006;72(2):227-34.

34. Matas CG, Hataiama CNM, Gonçalves IC. Stability of auditory evoked potentials in adults with normal hearing. Rev Soc Bras Fonoaudiol. 2011;16(1):37-41. 